Jurnal Interpretasi Hukum | ISSN: 2746-5047

Vol. 2, No. 3-Desember 2021, Hal. 597-601| Tersedia online di

https://www.ejournal.warmadewa.ac.id/index.php/juinhum

DOI: https://doi.org/10.22225/juinhum.2.3.4143.597-601

\title{
SANKSI PIDANA TERHADAP PEMBERI KERJA DALAM UNDANG-UNDANG NO. 11 TAHUN 2020 TENTANG CIPTA KERJA
}

\author{
Kalingga Maulana Ibrahim, I Nyoman Sugiartha, I Putu Gede Seputra \\ Fakultas Hukum, Universitas Warmadewa, Denpasar-Bali, Indonesia \\ kalinggam@gmail.com, nyomansugiartha14@gmail.com, gamyongputu@gmail.com
}

\begin{abstract}
Abs trak
Undang-undang Cipta Kerja merupakan undang-undang baru yang menuai kontroversi terutama dari kalangan buruh/pekerja dikarenakan RUU Cipta Kerja dinilai merugikan pekerja karena ketimpangan relasi kuasa dalam pembuatan kesepakatan. Tujuan penelitian ini guna mengungkap pengaturan hukum terhadap pemberi kerja dalam Undang-undang No.11 Tahun 2020 Tentang Cipta Kerja serta sanksi pidana terhadap pemberi kerja jika tidak memenuhi ketentuan Undang-undang Cipta Kerja. Jenis penelitian yang digunakan pada penelitian ini menggunakan jenis penelitian hukum normatif dengan pendekatan perundang-undangan dan pendekatan konseptual. Adapun teknik pengumpulan bahan hukum yaitu dilakukan teknik pencatatan, meringkas, maupun mengutip. Sumber data yang digunakan berupa data sekunder dan primer yang kemudian dianalisis secara kualitatif. Hasil penelitian mengungkapkan bahwa terdapat sanksi pidana bagi pengusaha yang membayarkan upah tenaga kerja di bawah upah minimum kabupaten/kota sebagaimana ketentuan pada Pasal 185 ayat 1 Undang-undang Cipta Kerja yaitu ancaman pidana bagi pelanggaran ketentuan pidana tersebut yaitu pidana bui dengan waktu paling singkat selama 2 tahun dan paling lama selama 4 tahun bui dan/atau denda sedikitnya 100 juta dan sebanyak banyaknya adalah 400 juta.
\end{abstract}

Kata Kunci: Cipta kerja, Pemberi Kerja, Sanksi Pidana

\begin{abstract}
The Job Creation Act is a new law that is causing controversy, especially among workers/workers because the Job Creation Bill is considered detrimental to workers due to the imbalance of power relations in making agreements. The purposes of this study are to reveal the legal arrangements against employers in Law No. 11 of 2020 concerning Job Creation and criminal sanctions against employers if they do not comply with the provisions of the Job Creation Act. The type of research used in this study uses a normative legal research type with a statutory approach and a conceptual approach. The techniques for collecting legal materials are recording, summarizing, and quoting techniques. Sources of data used in the form of secondary and primary data which are then analyzed qualitatively. The results of the study reveal that there are criminal sanctions for entrepreneurs who pay labor wages below the district/city minimum wage as stipulated in Article 185 paragraph 1 of the Job Creation Law, namely a criminal threat for violating the criminal provisions, namely imprisonment for a minimum period of 2 years and a maximum of 4 years in prison and/or a fine of at least 100 million and a maximum of 400 million.
\end{abstract}

Keywords: Job creation, Employment, Employer

\section{PENDAHULUAN}

Undang-undang Cipta Kerja merupakan kependekan dari 79 undang-undang yang telah ada sebelumnya, diantaranya terdapat juga Undang-undang No. 13 tahun 2003 tentang Ketenagakerjaan. Undang-undang ini bersifat memperbaiki, menambahkan dan juga mencabut pasal-pasal yang terdapat dalam Undang-undang sebelumya. Perubahan dilakukan dalam rangka penguatan perlindungan kepada tenaga kerja dan meningkatkan peran dan kesejahteraan pekerja/buruh dalam mendukung ekonomi investasi. Pemerintah meyakini bahwa perlu adanya Undang-undang ini demi membuka lapangan pekerjaan baru mempertimbangkan tingginya angka pengangguran di Indonesia. Masyarakat menilai undang-undang ini hanya menguntungkan bagi pemberi kerja dan justru merugikan pekerja sehingga pada saat prosesi pengesahannya menuai banyak opini-opini dari kalangan masyarakat hingga berujung demo di berbagai daerah di Indonesia, opini tersebut muncul mengingat waktu perencanaannya yang terkesan terlalu terburu-buru. Selain itu masyarakat juga mendesak pemerintah agar mengeluarkan perppu demi membatalkan undang-undang ini. Sebab, kehadiran RUU Cipta Kerja 
ini justru dapat mempercepat pertumbuhan ekonomi hanya bagi sektor privat dan justru berpotensi untuk mementingkan kelompok atau golongan tertentu (Aprianti et al., 2021). Adapun isu perlindungan terhadap tenaga kerja bukan hanya perlindungan akibat adanya pemutusan hubungan kerja, tapi juga perlindungan pada saat pekerja sedang melaksanakan kewajibannya dan memastikan pekerja mendapatkan haknya, Undang-undang Cipta Kerja sebagai pengubah sebagian Undangundang Ketenagakerjaan tentu saja berdampak kepada berubahnya tatanan sosial (Khair, 2021).

Terdapat poin-poin pasal yang dinilai berbenturan sehingga menuai sorotan seperti contohnya outsourcing, tidak adanya lagi pembatasan pekerja outsourcing dan batasan waktu kerja sebagai outsourcing. Selain itu beberapa materi dalam klaster ketenagakerjaan dinilai bermasalah dan menyisakan banyak pertanyaan. Materi tersebut antara lain terkait tenaga kerja asing, PKWT, pengupahan, PHK serta jaminan sosial. Selain pemberi kerja, tenaga kerja asing juga termasuk sebagai yang diuntungkan di dalam undang-undang ini karena pemberi kerja yang ingin mempekerjakan tenaga kerja asing pada perusahaannya hanya perlu memiliki izin tertulis dari menteri atau pejabat yang ditunjuk seperti yang tercantum dalam pasal 81 ayat 4 Undang-undang Cipta kerja.

Penelitian terdahulu yang relevan dengan penelitian ini mengungkapkan bahwa undangundang terkait Cipta Lapangan Kerja masih menyimpan sejumlah problematika normatif, yakni belum memberikan jaminan kepastian hukum bagi jaminan hak-hak pekerja, semisal penetapan upah yang layak dan kelayakan besaran pesangon (Sjaiful, 2021). Salah satu tujuan pembangunan ketenagakerjaan adalah memberikan pelindungan kepada tenaga kerja dalam mewujudkan kesejahteraan sebagaimana diatur dalam Pasal 4 huruf c UU Ketenagakerjaan yang berupa pelindungan ekonomis, sosial, dan teknis (Tobing, 2021). Dalam UU Cipta kerja menunjukkan adanya kelemahan, khususnya berkaitan dengan aspek hak asasi manusia khususnya mengenai hak atas pekerjaan, serta dalam upaya perlindungan bagi buruh terhadap kondisi kerja yang layak dan adil, serta dalam upaya perlindungan hak atas lingkungan hidup yang layak karena pembentukan aturan yang bersifat melonggarkan regulasi yang bersifat restriktif dan pengenaan sanksi pidana lingkungan (Suntoro, 2021). Dari fenomena tersebut maka dilakukan penelitian yang bertujuan untuk mengungkap pengaturan hukum terhadap pemberi kerja dalam Undang-undang No.11 Tahun 2020 Tentang Cipta Kerja serta sanksi pidana terhadap pemberi kerja jika tidak memenuhi ketentuan Undang-undang Cipta Kerja.

\section{METODE PENELITIAN}

Tipe penelitian yang digunakan di dalam penelitian ini merupakan tipe penelitian dengan metode Normatif, yaitu tipe penelitian yang mengkaji hukum tertulis melalui berbagai aspek, yaitu aspek teori, perbandingan, struktur dan komposisi, lingkup dan materi, konsistensi, penjelasan umum dan pasal demi pasal, formalitas dan kekuatan meningkatkan suatu undang-undang, serta bahan hukum yang digunakan dengan pendekatan perundang-undangan dan pendekatan konseptual. Adapun teknik pengumpulan bahan hukum yaitu dilakukan teknik pencatatan, meringkas, maupun mengutip. Sumber data yang digunakan berupa data sekunder dan primer. Sumber bahan hukum primer yang didapat dengan menganalisis peraturan perundang-undangan, sedangkan bahan hukum sekunder didapat dari menganalisis buku-buku, jurnal-jurnal dan hasil-hasil penelitian terdahulu yang memiliki keterkaitan dengan judul penelitian ini. Setelah data terkumpul, kemudian dianalisis secara kualitatif dan disajikan dalam bentuk deskriptif.

\section{HASIL DAN PEMBAHASAN \\ 1. Pengaturan Hukum Terhadap Pemberi Kerja Dalam Undang-undang No.11 Tahun 2020 Tentang Cipta Kerja}

Maksud penataan Undang-undang Cipta Kerja tidak lain adalah untuk mensejahterakan serta membantu pencari kerja di Indonesia. Selain itu undang-undang ini bertujuan untuk menciptakan lapangan kerja yang lebih luas melalui kemudahan izin dalam berusaha. Dengan adanya aturan yang memudahkan pengusaha dalam menciptakan lapangan pekerjaan, maka diharapkan pertumbuhan investasi di Indonesia akan menjadi lebih baik sehingga investor lokal maupun asing akan menjadi tertarik untuk menanamkan modalnya di Indonesia dan menjadikan peluang terciptanya lapangan pekerjaan baru bagi pekerja akan semakin terbuka di berbagai sektor. Dengan terciptanya banyak lapangan kerja, perusahaan juga perlu menjadikan sertifikasi dan profesi sebagai syarat dalam bekerja 
demi menciptakan sumber daya manusia yang berkualitas. Pada era globalisasi peran sertifikasi kompetensi sangatlah penting, sertifikasi kompetensi merupakan sarana untuk meningkatkan daya saing tenaga kerja Indonesia supaya bisa bersaing dengan tenaga kerja asing.

Pemberi kerja merupakan pencipta lapangan pekerjaan yang dapat mempekerjakan tenaga kerja sehingga dapat mensejahterakan pekerja melalui pembayaran gaji sesuai dengan kesepakatan dari kedua belah pihak. Secara umum arti pemberi kerja perseorangan yaitu usaha yang hanya dimiliki oleh satu orang saja dan siapapun boleh mendirikannya dikarenakan sistemnya termasuk bebas dan tidak perlu adanya campur tangan dari pemerintah, namun di lain hal perseorangan masih sangat bergantung terhadap perusahaan lainnya terutama dalam urusan permodalan.

Subyek hukum dalam ilmu hukum ada dua yakni, orang dan badan hukum. Disebut sebagai subyek hukum oleh karena orang dan badan hukum menyandang hak dan kewajiban hukum (Syahrani, 2006). Undang-undang Cipta Kerja telah menggabungkan beberapa undang-undang menjadi satu dengan menambahkan, merubah ataupun menghapuskan beberapa pasal di dalam undang-undang sebelumnya termasuk Undang-undang Ketenagakerjaan yang dimana pemberi kerja maupun penerima kerja mempunyai aturan aturan yang berbeda dari yang telah ada sebelumnya seperti

1. Tenaga kerja asing

Undang-undang Cipta kerja menghapuskan ketentuan pasal 81 Undang-Undang Ketenagakerjaan, dimana pemberi kerja hanya perlu mendapatkan izin dari menteri atau pejabat yang ditunjuk untuk mempekerjakan tenaga kerja asing serta cukup memiliki Rencana Penggunaan Tenaga Kerja Asing.

2. PKWT

Pasal 59 telah diubah dimana pengaturan terhadap PKWT juga berubah serta menambahkan konsekuensi hukum bagi pemberi kerja yang tidak memenuhi syarat PKWT.

3. Alih daya/Outsourcing

Undang-undang Cipta Kerja dinilai membuat penggunaan pekerja alih daya semakin tidak dapat dikendalikan, karena tidak lagi diatur mengenai batasan pekerja apa saja yang tidak dilarang di dalam alih daya yang berarti memberikan peluang untuk mempekerjakan macam-macam pekerja termasuk pekerja lepas dan pekerja penuh.

4. Waktu kerja

Dalam sehari jam kerja serta lembur ditambahkan menjadi selama 4 jam atau dalam seminggu menjadi 18 jam, dimana di dalam Undang-undang sebelumnya jam kerja serta lembur hanya 3 jam dalam sehari atau 14 jam dalam satu minggu. Dengan demikian total keseluruhan waktu pekerja bisa mencapai 58 jam dalam seminggu. Namun pemberi kerja yang memberikan pekerjaan tambahan terhadap pekerja yang melebihi waktu bekerjanya harus didasari dengan perjanjian kerja antara kedua belah pihak.

5. Pengupahan

Pengupahan terhadap pekerja telah diubah sehingga upah minimum ditetapkan berdasarkan upah sektor serta upah di tingkat provinsi dan kabupaten/kota. Undang-undang Cipta Kerja juga memiliki konsep pengupahan yang di dasari dengan satuan waktu, namun memiliki potensi pendayagunaan dari pemberi kerja yang sangat besar. Untuk itu perlu diikuti dengan syarat yang ketat.

6. Pesangon

Ketentuan mengenai pesangon bagi pekerja yang terdampak PHK dimana besarannya hanya berdasarkan 25 kali besar upah dengan perincian 19 bulan upah dari perusahaan dan 6 bulan melalui BPJS ketenagakerjaan melalui program jaminan kehilangan pekerjaan. Pada Undang-undang sebelumnya adalah 32 kali upah bulanan pekerja.

7. PHK

Undang-undang Cipta Kerja menambahkan satu alasan perusahaan dapat melakukan PHK terhadap pekerja yaitu demi perusahaannya agar dapat lebih efisien.

\section{Sanksi Pidana Terhadap Pemberi Kerja jika Tidak Memenuhi Ketentuan Undang-undang Cipta Kerja}

Pada hakikatnya sejarah hukum pidana adalah sejarah dari pidana dan pemidanaan yang senantiasa mempunyai hubungan erat dengan masalah tindak pidana (Sudarto, 1986). Sanksi pidana memiliki bentuk yang bervariasi seperti, pidana mati, pidana seumur hidup, pidana penjara, pidana kurungan 
dan pidana denda yang merupakan pidana pokok, serta pidana berupa pencabutan hak-hak tertentu, perampasan barang-barang tertentu dan pengumuman putusan hakim yang keseluruhannya merupakan pidana tambahan (Ali, 2011). Sanksi pidana merupakan sanksi yang penerapannya di masyarakat paling sering terjadi atau paling banyak kasusnya Sanksi pidana memiliki banyak jenis bentuknya seperti : (1) pidana Mati yaitu pidana yang sangat dikenal di sekitar masyarakat. Pidana mati merupakan hukuman dengan level paling berat yang dapat dijatuhkan kepada seseorang atas apa yang telah diperbuatnya. Penerapan hukuman mati dalam hukum pidana di banyak belahan dunia dilakukan dengan cara yang beragam mulai dari dipenggal, dipancung, dihimpit, penusukan, dibunuh dengan kursi listrik sampai ditembak mati; (2) pidana Penjara merupakan pidana yang membatasi kebebasan bergerak dari seorang terpidana dengan menempatkan pada sebuah Lembaga Pemasyarakatan (LP) dimana terpidana harus mentaati segala peraturan yang ditetapkan bagi mereka yang melanggar (Lamintang, 1986).

Tujuan dilakukannya hal itu guna mengubah terpidana menjadi insan dengan norma dan sifatnya dapat dibanggakan bagi masyarakat, bangsa maupun Negara.

1) Pidana Kurungan

Pidana Kurungan merupakan kemiripan dari pidana sebelumnya dimana pidana ini sama sama mencabut kemerdekaan seorang yang menjadi terpidana hanya saja jenisnya yang lebih ringan dengan kurun waktu paling sedikit adalah satu hari dan paling lama satu tahun.

\section{2) Pidana Denda}

Pidana denda merupakan pidana yang diarahkan terhadap harta kekayaan atau benda dari seorang terpidana yang melakukan pelanggaran terhadap aturan hukum pidana yang berlaku. Indonesia hanya menjadikan Pidana denda sebagai pidana alternatif sebabnya ialah nilai mata uang rupiah yang semakin lama semakin menurun. Hal ini disebabkan karena nilai uang rupiah semakin lama semakin merosot, maka menyebabkan nilai uang yang diancamkan pada rumusan tindak pidana tidak dapat mengikuti nilai uang di pasaran dan terkesan menimbulkan ketidakadilan jika pidana denda dijatuhkan (Pawennei, 2015).

\section{3) Pidana Tutupan}

Pidana tutupan ini merupakan pidana yang juga diatur dalam pasal 10 KUHP dan pidana ini dapat dikatakan sebagai pidana pengganti pidana penjara. Penempatan terdakwa pidana tutupan ditempatkan khusus di rumah tutupan yang diurus oleh menteri pertahanan dimana penghuni nya tidak boleh dipekerjakan apabila memasuki hari libur atau hari raya kecuali jika terpidana itu sendiri yang menginginkannya. Selain itu adapun pidana yang perannya sangat penting di dalam hukum pidana Indonesia yaitu pidana tambahan. Pidana ini bertujuan untuk melindungi masyarakat terhadap oknum-oknum pelaku tindak pidana, maka sudah sewajarnya jika pidana tambahan dikenakan terhadap oknum-oknum tindak pidana sesuai dengan jenis-jenis pidana tambahan di samping pidana pokok.

Pemberi kerja terdiri dari perseorangan, pengusaha, badan hukum atau badan-badan lainnya yang memiliki kontrak ataupun kesepakatan kerja dengan tenaga kerja dengan membayarkan upah ataupun imbalan, sesuai dengan pasal 1 ayat 4 undang-undang ketenagakerjaan. Sedangkan tenaga kerja merupakan orang-orang yang dapat melakukan pekerjaan guna menghasilkan barang ataupun jasa demi memenuhi kebutuhan sendiri ataupun kebutuhan masyarakat. Pemberi kerja maupun pekerja keduanya saling berkaitan dan memiliki hubungan di dalam perjanjian kerja atau dapat dibilang perjanjian kerja inilah yang merupakan hubungan kerja. Apapun tindakan pemberi kerja perlu memperhatikan ketentuan yang berlaku agar tidak terjadi pelanggaran HAM, untuk itu pelaksanaan hubungan kerja perlu keikutsertaan Negara dalam mengatur hal-hal tertentu melalui Undang-undang. Untuk itu diaturlah sanksi-sanksi pidana dalam hal tindak pidana di dalam dunia ketenagakerjaan yang dimana fungsinya sebagai sarana dalam penegakan hukum melalui pemberian hukuman kepada pengusaha apabila terjadi tindak pidana.

Dalam Undang-undang Ketenagakerjaan, sanksi pidana diatur dalam pasal 183-188 dan juga dalam pasal 189 menegaskan bahwasannya pemberi kerja tetap harus membayar hak-hak/ganti rugi kepada tenaga kerjanya walaupun pemberi kerja tersebut sedang dalam proses pidana. Pada Undangundang Cipta Kerja mengubah/ menghapuskan dan juga menambahkan sanksi dalam Undang-undang sebelumnya seperti

a. Pasal 184 dihapuskan karena ketentuan pasal 167 juga telah dihapuskan. 
b. Pasal 185 dimana menghapuskan ketentuan pasal 42 ayat 1 , pasal 90 ayat 1 , dan 160 ayat 7 selain itu ditambahkan ketentuan pasal $88 \mathrm{E}$ ayat 2 dan 156 ayat 1.

c. Pasal 186 dimana pasal ini menghapuskan ketentuan pada undang-undang sebelumnya yaitu Pasal 137 dan Pasal 138.

d. Pasal 187 dimana menghapuskan ketentuan Pasal 37 ayat 2 dan Pasal 44 ayat 1, serta menambahkan ketentuan Pasal 79 ayat 3.

e. Pasal 188 hanya menghapuskan ketentuan Pasal 14 ayat 2 dalam undang-undang sebelumnya.

\section{SIMPULAN DAN SARAN}

\section{Simpulan}

Mengenai pengaturan Peraturan Perundang-undangan No.11 Tahun 2020 dapat diketahui jika proses mengerjakan terlalu bersicepat sehingga menghadirkan berbagai prospek dari kalangan masyarakat. Kendati begitu Undang-undang ini memiliki kekurangan dan juga memiliki kelebihan dimana tidak sedikit regulasi yang malah merugikan untuk pekerja, antara lain merupakan terkait dengan upah minimum, pesangon, alih daya, waktu istirahat, perjanjian kerja dan masih banyak lagi menimbangnimbang dengan Undang-Undang Ketenagakerjaan. Adapun sanksi pidana di dalam undang-undang cipta kerja memiliki keuntungan dan kerugian dari sisi pemberi kerja maupun sisi pekerja, contohnya penegasan terhadap sanksi pidana bagi pengusaha yang membayarkan upah tenaga kerja di bawah upah minimum kabupaten/kota. Penegasan sanksi tersebut apabila jika pengusaha melakukan pelanggaran terhadap sanksi tersebut, pekerja dapat melakukan hal-hal seperti menempuh upaya pidana dengan mengadukan kepada pihak berwajib seperti kepolisian. Ancaman pidana bagi pelanggaran ketentuan pidana tersebut yaitu pidana bui dengan waktu paling singkat selama 2 tahun dan paling lama selama 4 tahun bui dan/atau denda sedikitnya 100 juta dan sebanyak banyaknya adalah 400 juta. Sebagaimana ketentuan pada Pasal 185 ayat 1 Undang-undang Cipta Kerja.

\section{Saran}

Bagi pekerja perlunya untuk lebih memahami terkait undang-undang serta sanksi-sanksi yang tertera di dalam undang-undang yang berlaku karena pekerja perlu juga mengetahui apa yang menjadi hakhaknya di samping kewajiban-kewajiban yang harus dipatuhi pekerja. Selain itu bagi pemerintah, pengusaha dan pekerja juga perlu akan kesadaran atas penegakan hukum di bidang ketenagakerjaan. Sedangkan bagi pemerintah perlu mengkaji dengan seksama kembali pasal demi pasal yang terdapat di dalam undang-undang cipta kerja karena kurangnya aspek kemanusiaan di dalamnya.

\section{DAFTAR PUSTAKA}

Ali, M. (2011). Dasar-Dasar Hukum Pidana. Sinar Grafika, Jakarta.

Aprianti, N., Safa'at, M. A., \& Qurbani, I. D. (2021). Dualisme Model Pengujian Peraturan Daerah Pasca Undang-undang Nomor 11 Tahun 2020 Tentang Cipta Kerja. Jurnal IUS Kajian Hukum Dan Keadilan, 9(2), 472-485.

Khair, O. I. (2021). Analisis Undang-undang Cipta Kerja Terhadap Perlindungan Tenaga Kerja di Indonesia. Widya Pranata Hukum, 3(2), 45-63.

Lamintang, P. A. F. (1986). Hukum Penitensier Indonesia. Arimeco, Bandung.

Pawennei, M. (2015). Hukum Pidana. Mitra Wacana Media, Jakarta.

Sjaiful, M. (2021). Problematika Normatif Jaminan Hak-Hak Pekerja Dalam Undang-undang Nomor

11 Tahun 2020 Tentang Cipta Kerja. Media Iuris, 4(1), 37-60.

Sudarto. (1986). Hukum dan Hukum Pidana. Alumni, Bandung.

Suntoro, A. (2021). Implementasi Pencapaian Secara Progresif dalam Omnibus Law Cipta Kerja. Jurnal HAM, 12(1), 1-18.

Syahrani, R. (2006). Seluk beluk dan Asas Asas Hukum Perdata. Alumni, Bandung.

Tobing, C. N. (2021). UU Cipta Kerja Mewujudkan Harmonisasi Kebijakan Strategis Nasional. Pelindungan Dan Kesejahteraan Pekerja Dalam Undang-Undang Cipta Kerja. 